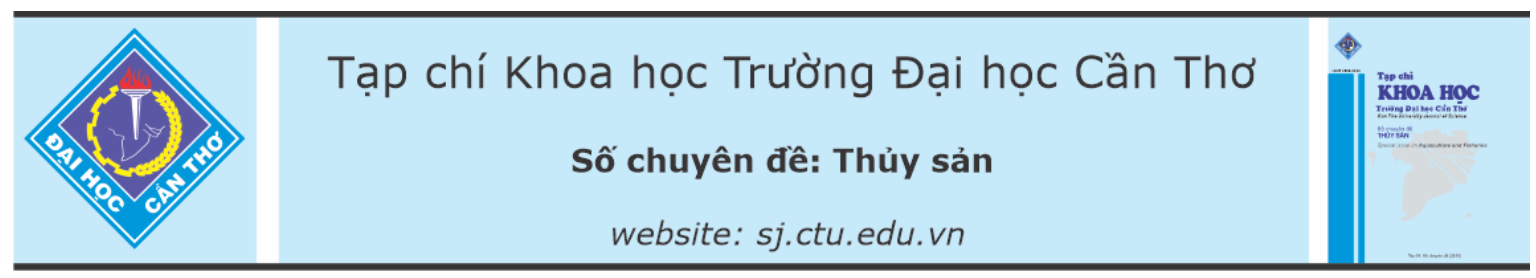

DOI:10.22144/ctu.jvn.2021.067

\title{
ẢNH HƯởNG CỦA DỊCH CHIẾT CÂY DIỆP HẠ CHÂU (Phyllanthus amarus Schum. AND Thonn) ĐẾN CHẤT LƯợNG TÔM SÚ (Penaeus monodon) TRONG ĐIỀU KIỆN BẢO QUẢN LẠNH
}

Trần Minh Phú ${ }^{*}$, Huỳnh Thị Kim Duyên ${ }^{1}$, Nguyễn Lê Anh Đào ${ }^{1}$, Hồ Quốc Phong ${ }^{2}$, Nguyễn Thị Như Hạ ${ }^{1}$, Nguyễn Trọng Tuân ${ }^{3}$, Nguyễn Quốc Thịnh ${ }^{1}$ và Tomoaki Hagiwara ${ }^{4}$

${ }^{1}$ Khoa Thủy sản, Truò̀ng Đại học Cần Tho, Việt Nam

${ }^{2}$ Khoa Công nghệ, Truờng Đại học Cần Thoo, Việt Nam

${ }^{3}$ Khoa Khoa học Tụ nhiên, Truờng Đại học Cần Tho, Việt Nam

${ }^{4}$ Department of Food Science and Technology, Tokyo University of Marine Science and Technology, Japan

*Ngưòi chịu trách nhiệm về bài viết: Trần Minh Phú (email: tmphu@ctu.edu.vn)

\section{Thông tin chung:}

Ngày nhận bài: 22/02/2021

Ngày nhận bài sủa: 12/04/2021

Ngày duyệt đăng: 01/06/2021

\section{Title:}

The effect of Phyllanthus amarus extract on the quality of the whole black tiger shrimp during ice storage

\section{Tùr khóa:}

Bảo quản lạnh, chất luợng, dịch chiết, diệp ha châu, tôm sú

\section{Keywords:}

Black tiger shrimp, extract, ice storage, Phyllanthus amarus, quality

\begin{abstract}
The study was conducted to evaluate the use of Phyllanthus amarus Schum. and Thonn extract in the quality of the black tiger shrimps under ice storage. The experiment consisted of three treatments. Shrimp (25-30 g) were soaked in P. amarus extract solution with concentrations of $7.71 \mu \mathrm{g} / \mathrm{mL}$ and 156 $\mu \mathrm{g} / \mathrm{mL}$ or in iced water (control treatment) at $0-4^{\circ} \mathrm{C}$ for 30 minutes. Shrimps after soaking were stored in ice and samples were collected on days 1, 4, 8, and 12. Changes in shrimp quality were evaluated through total aerobic bacteria count, sensory analysis, elasticity, water holding capacity, total volatile base nitrogen, peroxyde value, thiobarbituric acid reactive substances, moisture and $\mathrm{pH}$. The results showed that black tiger shrimp treated with P. amarus at concentration of 7,71 $\mu \mathrm{g} / \mathrm{mL}$ and $156 \mu \mathrm{g} / \mathrm{mL}$ showed significantly higher sensory properties, and slighly lower primary and secondary oxidation products and total aerobic bacterial counts compared to the control samples during ice storage. Based on the sensory properties and total aerobic bacteria count, black tiger shrimps can be used up to 8 days.
\end{abstract}

\section{TÓM TẮT}

Nghiên cứu được thưc hiện nhằm đánh giá khả năng sủ dung dịch chiết diệp hạ châu đến chất luợng của tôm sú trong điều kiện bảo quản lạnh. Thi nghiệm gồm 3 nghiệm thức. Tôm $(25-30 \mathrm{~g} / \mathrm{con})$ được ngâm trong dịch chiết diệp ha châu với nồng độ khác nhau $7,71 \mu \mathrm{g} / \mathrm{mL}, 156 \mu \mathrm{g} / \mathrm{mL}$ và ngâm trong nước lạnh (nghiệm thức đối chúng) ${ }^{\circ} 4^{\circ} \mathrm{C}$ trong 30 phút. Tôm sau khi ngâm được bảo quản bằng nước đá và thu mẫu được thưc hiện vào các ngày 1, 4, 8 và 12. Sự biến đổi chất lương của tôm được đánh giá qua các chỉ tiêu nhu tổng số vi khuẩn hiếu khi, điểm cảm quan, độ đàn hồi, khả năng giữ nước, tổng luợng nito base bay hoi, chỉ số peroxyde, chỉ số TBARs, ẩm độ và $p H$. Kết quả cho thấy tôm sú có xư lý diệp hạ châu $7,71 \mu \mathrm{g} / \mathrm{mL}$ và $156 \mu \mathrm{g} / \mathrm{mL}$ có giá trị cảm quan cao hơn tôm sú ớ mẫu đối chứng trong suốt 12 ngày của quá trình bảo quản lạnh. Tôm được xử lý với dịch chiết diệp hạ châu có khả năng làm giảm sự phát triển của tổng vi khuẩn hiếu khi và ức chế một phần hình thành sản phẩm oxy hóa sơ cấp và thú cấp. Dựa vào kết quả đánh giá cảm quan và tổng số vi khuẩn hiếu khí cho thấy tôm sú có thể sử dụng đến 8 ngày. 


\section{GIỚI THIỆU}

Nuôi trồng thủy sản Việt Nam đang trên đà phát triển, sản lượng nuôi và giá trị xuất khẩu chủ yếu là cá tra và tôm. Cả năm 2019, diện tích nuôi tôm đạt 720.000 ha, sản lượng tôm nước lợ ước đạt 750 nghìn tấn bằng $98,3 \%$ so với năm 2018 , trong đó tôm sú ước đạt 270.000 tấn, tôm thẻ chân trắng là đạt 480.000 tấn (Hiệp hội Chế biến và Xuất khẩu Thủy sản Việt Nam [VASEP], 2020). Tôm sú là loài thực phẩm có giá trị dinh dưỡng cao, chứa nhiều chất đạm, các vitamin và nguyên tố vi lượng. Tôm không những là nguồn cung cấp đạm dồi dào mà còn chứa nhiều các acid béo Omega-3, tốt cho sức khỏe và giúp phòng ngừa bệnh tim mạch. Tôm cũng chứa nhiều chất thiết yếu cho da, xương và răng như calcium, zinc, phosphorus, iron, magnesium (Gunalan et al., 2011).

Một số nghiên cứu cho thấy trong cây diệp hạ châu chứa hàm lượng phenolic cao và có khả năng chống oxy hóa tốt (Maity et al., 2003, Sen \& Batra, 2012). Sử dụng các chất từ tự nhiên để chế biến và bảo quản thực phẩm thay thế cho các hóa chất tổng hợp đã và đang được nghiên cứu và sử dụng bởi tính an toàn và hiệu quả của nó (Cos et al., 2006; Solanki, 2010). Nhiều nghiên cứu sử dụng dịch chiết thực vật trong bảo quản tôm đã được thực hiện. Chẳng hạn, Nirmal and Beenjakul (2011) đã nghiên cứu ảnh hưởng của việc sử dụng dịch chiết trà xanh kết hợp với acid ascorbic và bao gói MPA trong quá trình bảo quản lạnh tôm thẻ chân trắng. Yuan et al. (2016b) nghiên cứu ảnh hưởng của dịch chiết trà xanh kết hợp với chitosan đến chất lượng của tôm thẻ chân trắng trong điều kiện bảo quản lạnh ở nồng độ trà $(1 \%)$ bằng phương pháp nhúng kết hợp với chitosan (1\%). Yuan et al. (2016a) cũng khảo sát chất lượng của tôm thẻ chân trắng trong việc sử dụng dịch chiết vỏ quả lựu kết hợp chitosan trong 10 ngày bảo quản lạnh. Tuy nhiên, chưa có nhiều nghiên cứu sử dụng các hoạt chất tự nhiên trong bảo quản tôm sú. Vì vậy, nghiên cứu "Ảnh hưởng của dịch chiết cây diệp hạ châu (Phyllanthus amarus Schum and Thonn) lên bảo quản lạnh tôm sú (Penaeus monodon)" được thực hiện là rất cần thiết nhằm cung cấp thông tin về khả năng sử dụng chất chống oxy hóa trong bảo quản tôm cũng như xác định thời gian bảo quản sản phẩm thông qua sự biến đổi của các thông số chất lượng sản phẩm như cảm quan, vi sinh và hóa học.

\section{PHƯƠNG PHÁP NGHIÊN CÚU}

\subsection{Vật liệu nghiên cứu}

Tôm sú (25-30 g) được mua từ đại lý thu mua tôm quãng canh ở Đầm Dơi, Cà Mau. Tôm được bắt buổi sáng sớm tại ao nuôi và ướp đá chuyển về Đầm Dơi, khoảng cách trung bình từ $5-10 \mathrm{~km}$ với thời gian vận chuyển từ $1-2$ giờ. Tôm được rửa bằng nước sạch, phân cỡ và bố trí thí nghiệm nhúng tôm với dịch chiết tại Đầm Dơi, Cà Mau. Tôm sau đó được bảo quản lạnh bằng nước đá $(1: 1)$ và vận chuyển đến Khoa Thủy sản, Trường Đại học Cần Tho.

Cao chiết diệp hạ châu được chuẩn bị tại Khoa Khoa học Tự nhiên, Trường Đại học Cần Thơ. Lá và cành diệp hạ châu được phơi khô và chiết bằng dung môi ethanol 96\%, tỷ lệ lá và cành diệp hạ châu và dung môi là $1: 8$, thời gian ngâm chiết là 24 giờ, dịch chiết được thu hồi qua bốn lần chiết và cô cạn bằng máy cô quay chân không để thu được cao chiết. Cao chiết được bảo quản trong tủ đông $-20 \pm 2{ }^{\circ} \mathrm{C}$ cho đến khi sử dụng. Nồng độ dịch chiết diệp hạ châu được chọn với nồng độ $7,71 \mu \mathrm{g} / \mathrm{mL}$ tương ứng với nồng độ ức chế $50 \%$ gốc tự do $\mathrm{DPPH}\left(\mathrm{IC}_{50}\right)$ và nồng độ ức chế tối thiểu sự phát triển của vi sinh vật (MIC) là $156 \mu \mathrm{g} / \mathrm{mL}$ dựa theo kết quả nghiên cứu của Le Anh Dao et al. (2020).

\subsection{Phương pháp nghiên cứu}

\subsubsection{Bố trí thí nghiệm}

Thí nghiệm gồm 3 nghiệm thức bảo quản trong điều kiện nước đá: nghiệm thức (1) tôm sú không có xử lý dịch chiết, nghiệm thức (2) tôm sú xử lý ngâm dịch chiết diệp hạ châu với nồng độ $7,71 \mu \mathrm{g} / \mathrm{mL}$, nghiệm thức (3) tôm sú xử lý dịch chiết diệp hạ châu với nồng độ $156 \mu \mathrm{g} / \mathrm{mL}$.

Bố trí thí nghiệm: tôm sú (360 con; 25-30 g/con) được phân bố hoàn toàn ngẫu nhiên vào các nghiệm thức. Nghiệm thức 1 gồm 120 con được ngâm với nước (mẫu đối chứng, (tỷ lệ khối lượng tôm và thể tích dung dịch 1:1) trong 30 phút ở điều kiện lạnh, nhiệt độ $<4^{\circ} \mathrm{C}$, sau đó vớt ra, để ráo 5 phút và cho 30 con tôm vào túi $\mathrm{PA}$ và hàn miệng và bảo quản trong điều kiện nước đá với tỷ lệ tôm : nước đá là 1:1. Các túi được đặt trong thùng xốp, nước đá được phân bố theo nguyên tắc 1 lớp đá và 1 lớp tôm, lớp dưới cùng và lớp trên cùng là nước đá. Nghiệm thức 2 và nghiệm thức 3 gồm 120 con tôm mõi nghiệm thức được ngâm vào dịch chiết diệp hạ châu với nồng độ $7,71 \mu \mathrm{g} / \mathrm{mL}$ và $156 \mu \mathrm{g} / \mathrm{mL}$ trong 30 phút ở điều kiện lạnh, nhiệt độ $<4^{\circ} \mathrm{C}$, sau đó tiến hành thực hiện các thao tác tương tự như nghiệm thức 1 . Trong thời gian bảo quản, nước được loại bỏ mỗi ngày và nước đá được bổ sung nhằm đảm bảo tỷ lệ của nước đá và tôm là 1:1. Thí nghiệm được thực hiện tại Đầm Dơi, Cà Mau. 
Thu mẫu được thực hiện tại Khoa Thủy sản, Trường Đại học Cần Thơ. Trong mỗi lần thu mẫu, ở mỗi nghiệm thức lấy 1 túi PA chứa 30 con tôm. Đo nhiệt độ 4 con tôm trước khi lấy tôm ra khỏi thùng xốp. Lấy ngẫu nhiên 4 con tôm cho phân tích tổng số vi khuẩn hiếu khí, tiếp tục lấy 7 con tôm để đánh giá cảm quan, 4 con tôm lột vỏ để đo độ đàn hồi, 4 con nghiền nhuyễn cho phân tích tổng nitơ base bay hơi (TVB-N), chỉ số peroxyde (PV), thiobarbituric acid reactive substances (TBARs), phần thị tôm còn lại được đem xay nhuyễn để kiểm tra lần lượt các chỉ tiêu: $\mathrm{pH}$, khả năng giữ nước (WHC) và ẩm độ. Mẫu được thu vào các ngày $1,4,8$ và 12 . Thu mẫu và phân tích mẫu được thực hiện như nhau ở các lần thu mẫu.

\subsubsection{Phưong pháp phân tích mẫu và đo đạc}

\section{Nhiệt độ}

Vào các ngày thu mẫu, nhiệt độ $\left({ }^{\circ} \mathrm{C}\right)$ tâm sản phẩm được đo bằng nhiệt kế (Ebro, Đức), thực hiện đo trên 4 con tôm ở mỗi nghiệm thức tương ứng với 4 lần lặp lại, trước khi lấy ra khỏi thùng xốp, thực hiện đo nhiệt độ ở cùng một vị trí trên mỗi con tôm.

\section{pH}

pH trong cơ thịt tôm được đo theo phương pháp mô tả bởi Hultmann et al. (2012). Mẫu tôm xay nhuyễn $(20 \mathrm{~g})$ được trộn đều với $20 \mathrm{~mL} \mathrm{KCl} \mathrm{0,15M}$. Hỗn hợp được đo bằng máy đo $\mathrm{pH}$ (Mettler Toledo, USA). Mỗi nghiệm thức được lặp lại 3 lần.

\section{Xác định độ đàn hồi}

Mẫu đo độ đàn hồi được chuẩn bị cùng một vị trí cho tất cả các con tôm, phần cơ thịt dày nhất cách đầu $1 \mathrm{~cm}$ được chọn. Đo độ đàn hồi cơ thị tôm $\left(\mathrm{g}^{*} \mathrm{~cm}\right)$ vào các ngày thu mẫu bằng máy đo cấu trúc TA.Xt2i Texture Analyser (Stable Micro Systems, $\mathrm{YL}, \mathrm{UK})$, sử dụng đầu dò $\mathrm{P} / 5 \mathrm{~S}$ với tốc độ di chuyển đầu đo là $60 \mathrm{~mm} /$ phút, thời gian giữ là 2 giây, độ xuyên thấu $5 \mathrm{~mm}$. Mỗi nghiệm thức được lặp lại 3 lần tương ứng với 3 con tôm.

\section{Khả năng giữ nước (WHC, \%)}

Cân $1,5 \mathrm{~g}$ mẫu tôm đã xay nhuyễn cho vào ống ly tâm $15 \mathrm{~mL}$ có chứa bộ phận lọc và ly tâm ở $4^{\circ} \mathrm{C}$ trong thời gian 10 phút với tốc độ $300 \mathrm{~g}$. Khối lượng nước mất đi trong quá trình ly tâm phản ánh khả năng giữ nước của sản phẩm (Ofstad et al., 1993). Mỗi nghiệm thức được lặp lại 3 lần.

\section{Ẩm độ}

Cân $2 \mathrm{~g}$ mẫu đem đi sấy ở tủ sấy $60^{\circ} \mathrm{C}$ trong 2 ngày, sau đó chuyển qua tủ sấy $105^{\circ} \mathrm{C}$ trong 2 ngày rồi đem cân lại. Tính hàm lượng ẩm $(\%)$ theo AOAC (2016). Mỗi nghiệm thức được lặp lại 3 lần.

\section{Tổng lượng nitơ base bay hơi (Total Volatile Base Nitrogen, TVB-N)}

Tổng hàm lượng nitơ base bay hơi (TVB-N) được phân tích theo phương pháp Velho (2001); cân $5 \mathrm{~g}$ mẫu $( \pm 0,1 \mathrm{~g})$ cho vào ống chưng cất (ống Kjeldahl) của thiết bị chưng cất (Vapodest, Gerhardt, Germany); cho tiếp $2 \mathrm{~g} \mathrm{MgO}$ và $50 \mathrm{~mL}$ nước cất vào ống, lắp ống Kjeldahl vào hệ thống chưng cất; lắp bình tam giác chứa $25 \mathrm{~mL}$ acid boric $1 \%$ vào hệ thống chưng cất; sau đó tiến hành chưng cất trong 10 phút. Sau khi chưng cất mẫu xong, tiến hành chuẩn độ dung dịch thu được trong bình tam giác bằng dung dịch chuẩn $\mathrm{H}_{2} \mathrm{SO}_{4} 0,1 \mathrm{~N}$ cho đến khi dung dịch chuyển từ màu xanh lá cây sang màu hồng; sau đó tính toán kết quả. Mỗi nghiệm thức được lặp lại 3 lần.

\section{Chỉ số peroxyde}

Chỉ số peroxyde được xác định theo phương pháp chuẩn độ theo tiêu chuẩn AOAC (2016). Cân $5 \mathrm{~g}$ tôm đã nghiền nhuyễn cho vào ống fancol 50 $\mathrm{mL}$, cho thêm $20 \mathrm{~mL}$ dd chloroform : methanol (2 : $1)$, và lắc mẫu 1 giờ bằng máy lắc. Sau khi lắc mẫu xong, dùng muỗng vớt bỏ phần cái, chiết phần dung dịch chuyển sang 2 ống fancol $15 \mathrm{~mL}$ để ly tâm với tốc độ $700 \mathrm{~g}$ ở $25^{\circ} \mathrm{C}$ trong 5 phút. Sau khi ly tâm, hút lấy phần dung dịch phía dưới ống sang ống fancol $50 \mathrm{~mL}$ khác để chuẩn bị cho các phân tích sau. Sau đó cho $10 \mathrm{~mL}$ dịch chiết và $25 \mathrm{~mL}$ dung dịch acetic acid : chloroform $(3: 2)$ vào bình tam giác $250 \mathrm{~mL}$, thêm $1 \mathrm{~mL}$ dung dịch $\mathrm{KI}$ lắc đều trong 1 phút (dung dịch KI bão hòa phải được pha mới hoàn toàn) và đem đi ủ trong tối khoảng 5 phút để phản ứng xảy ra hoàn toàn. Sau khi ủ xong, thêm 75 $\mathrm{mL}$ nước cất, lắc đều, nhỏ $1 \mathrm{~mL}$ chất chỉ thị hồ tinh bột $1 \%$ (xuất hiện màu xanh tím) và tiến hành chuẩn độ bằng dung dịch $\mathrm{Na}_{2} \mathrm{~S}_{2} \mathrm{O}_{3} 0,01 \mathrm{~N}$, chuẩn độ đến khi dung dịch mẫu từ màu xanh tím chuyển sang mất màu thì dừng lại, ghi kết quả thể tích dung dịch $\mathrm{Na}_{2} \mathrm{~S}_{2} \mathrm{O}_{3} \quad 0,01 \mathrm{~N}$, sau đó tính toán kết quả. Mỗi nghiệm thức được lặp lại 3 lần.

\section{Thiobarbituric Acid Reactive substances (TBARs)}

TBARs được phân tích theo phương pháp so màu quang phổ của Raharjo et al. (1992); chuần bị dung dịch mẫu tương tự như đối với phân tích $\mathrm{PV}$; cân $8 \mathrm{~g}$ mẫu vào ống Falcon $50 \mathrm{~mL}$, cho $15 \mathrm{~mL}$ TCA (Tricloroacetic acid) $5 \%$ vào nghiền kỹ rửa máy nghiền với $5 \mathrm{~mL}$ TCA $5 \%$ và thu lại dung dịch, chia đều mẫu ra hai ống ly tâm $15 \mathrm{~mL}$ và ly tâm trong 15 phút ở $1050 \mathrm{~g}$, lọc lấy phần nổi lên trên qua bình định mức $50 \mathrm{~mL}$. Thêm vào phần kết tủa $10 \mathrm{~mL}$ 
TCA $5 \%$, nghiền bằng máy nghiền, rửa đầu trục máy nghiền với $5 \mathrm{~mL}$ TCA $5 \%$ và thu lại dung dịch, chia đều mẫu ra hai ống ly tâm $15 \mathrm{~mL}$ và ly tâm trong 15 phút ở $1050 \mathrm{~g}$, tiếp tục cho phần dung dịch nổi vào bình định mức $50 \mathrm{~mL}$. Đối với mẫu TEP cho thêm vào $1 \mathrm{~mL}$ TEP sau đó làm tương tự như trên. Định mức dung dịch bằng dung dịch TCA $5 \%$ lên $50 \mathrm{~mL}$. Phân tích mẫu được thực hiện bằng cách hút $2 \mathrm{~mL}$ mẫu đã được lọc và $2 \mathrm{~mL}$ TBA $5 \%$ đem đi vortex rồi đun ở $94^{\circ} \mathrm{C}$ trong 5 phút, cho vào thau nước lạnh để làm nguội và tiến hành so màu quang phổ với bước sóng $530 \mathrm{~nm}$. Hàm lượng TBARs được tính thông qua đường chuẩn TEP. Mỗi nghiệm thức được lặp lại 3 lần.

\section{Tổng số vi khuẩn hiếu khí}

Tổng số vi khuẩn hiếu khí được xác định theo phương pháp đổ đĩa (Bộ Y tế, 2012). Mẫu tôm (3 con/nghiệm thức) được lấy ngẫu nhiên từ bao chứa, mỗi con tôm được xử lý riêng biệt, loại bỏ vỏ đầu và nghiền nhuyễn. Mẫu tôm ( $1 \mathrm{~g} / \mathrm{con})$ được pha loãng vào ống nước muối sinh lý với các mức độ pha loãng khác nhau; sau khi pha loãng, tiến hành hút $1 \mathrm{~mL}$ dung dịch cho vào đĩa petri, mỗi nồng độ 2 đĩa; sau đó cho môi trường Plate Count Agar (PCA, Merck, Đức) vào đĩa, mỗi đĩa khoảng $17-18 \mathrm{~mL}$ và xoay đều để mẫu đồng nhất. Khi môi trường đã khô, úp ngược đĩa lại và cho vào tủ ủ ở $30^{\circ} \mathrm{C}$ trong 48 giờ; sau đó, lấy đĩa ra đếm và tính kết quả.

\section{Đánh giá cảm quan}

Thực hiện đánh giá cảm quan tôm qua hai phương pháp: phương pháp chỉ số chất lượng Quality Index Method đánh giá mẫu tôm tươi theo Dương Thị Phượng Liên và ctv. (2011) và phương pháp Meilgaard et al. (1999) được dùng để đánh giá cảm quan mẫu tôm hấp. Hội đồng đánh giá gồm 7 thành viên. 7 con tôm được đặt trên đĩa màu trắng, sau đó 7 thành viên trong hội đồng đánh giá tiến hành đánh giá cảm quan. Đối với đánh giá cảm quan mẫu hấp, mẫu sau khi đánh giá cảm quan mẫu tươi sẽ được hấp trong 10 phút và chuẩn bị cho đánh giá cảm quan mẫu hấp.

\subsection{Xử lý số liệu}

Các số liệu của thí nghiệm được tính trung bình và độ lệch chuẩn bằng phần mềm Microsoft Excel 2013. Sự khác biệt trung bình của các chỉ tiêu phân tích ở các lần thu mẫu được xử lý bằng oneway ANOVA ở mức ý nghĩa $\mathrm{p}<0,05$ và phép thử Duncan, sử dụng chương trình SPSS 16.0

\section{KẾT QUẢ VÀ THẢO LUẬN}

\subsection{Sự thay đổi các tính chất hóa lý của tôm sú trong quá trình bảo quản lạnh}

\subsubsection{Sụ thay đổi nhiệt độ}

Ở các ngày thu mẫu, nhiệt độ tâm sản phẩm ở ba nghiệm thức dao động từ $1,18-1,28^{\circ} \mathrm{C}$. Nhiệt độ của thân tôm ghi nhận ở các ngày thu mẫu khác biệt không có ý nghĩa thống kê giữa ba ngiệm thức $(p>0,05)$. Như vậy, mẫu thí nghiệm luôn được bảo quản trong điều kiện lạnh nhỏ hơn $4^{\circ} \mathrm{C}$ đáp ứng yêu cầu của thí nghiệm bảo quản lạnh.

\subsubsection{Sụ thay đổi $p H$}

Kết quả đo $\mathrm{pH}$ trong suốt thời gian bảo quản cho thấy $\mathrm{pH}$ của mẫu có xử lý dịch chiết có giá trị thấp hơn và khác biệt có ý nghĩa thống kê so với mầu đối chứng ở các ngày $1,4,12(p<0,05)$ (Bảng 1$)$. Sự thay đổi $\mathrm{pH}$ của cơ thịt tôm trong quá trình bảo quản chủ yếu là do sự phân hủy ATP và glycogen giải phóng $\mathrm{ra} \mathrm{H}^{+}$làm cho giá trị $\mathrm{pH}$ thay đổi trong quá trình bảo quản. Thêm vào đó, sau một thời gian bảo quản thì acid amin và các chất hữu cơ bị phân hủy do các enzyme phân giải protein và hoạt động của vi sinh vật tạo thành $\mathrm{NH}_{3}$ làm $\mathrm{pH}$ của cơ thịt tôm tăng lên (Dunn \& Rustad, 2007; Hultmann et al., 2012). Kết quả này phù hợp với kết quả phân tích TVB-N ở Hình 2, mẫu có xử lý dịch chiết sẽ ức chế một phần vi sinh vật và hoạt động phân giải protein của enzyme do đó giá trị pH ở mẫu tôm có xử lý dịch chiết có phần thấp hơn mẫu đối chứng trong thời gian bảo quản. Giá trị $\mathrm{pH}$ ngày 12 dao động từ $7,81-$ 7,95 phù hợp với kết quả nghiên cứu thay đổi chất lượng của tôm trong điều kiện bảo quản lạnh có giá trị pH là 7,98 (Zeng et al., 2005).

Bảng 1. Giá trị pH của tôm theo thời gian bảo quản lạnh do tác động của dịch chiết diệp hạ châu

\begin{tabular}{lrrrr}
\hline \multirow{2}{*}{ Nghiệm thức } & \multicolumn{4}{c}{ Ngày thu mẫu trong thời gian bảo quản (ngày) } \\
\cline { 2 - 5 } & $\mathbf{1}$ & $\mathbf{4}$ & $\mathbf{8}$ & $\mathbf{1 2}$ \\
\hline NT1 & $7,15 \pm 0,08^{\mathrm{c}}$ & $7,43 \pm 0,13^{\mathrm{b}}$ & $7,76 \pm 0,13^{\mathrm{a}}$ & $7,95 \pm 0,09^{\mathrm{b}}$ \\
NT2 & $7,04 \pm 0,04^{\mathrm{b}}$ & $7,31 \pm 0,11^{\mathrm{a}}$ & $7,74 \pm 0,09^{\mathrm{a}}$ & $7,81 \pm 0,09^{\mathrm{a}}$ \\
NT3 & $6,97 \pm 0,06^{\mathrm{a}}$ & $7,34 \pm 0,08^{\mathrm{ab}}$ & $7,72 \pm 0,13^{\mathrm{a}}$ & $7,85 \pm 0,07^{\mathrm{a}}$ \\
\hline
\end{tabular}

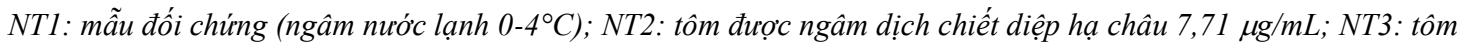
được ngâm dịch chiết diệp hạ châu $156 \mu \mathrm{g} / \mathrm{mL}$. Các chũ cái khác nhau trong cùng một ngày thu mẫu khác biệt có ý nghĩa thống kê $(p<0,05)$ 


\subsubsection{Khả năng giũ nước}

Khả năng giữ nước (WHC) trong cơ thịt tôm được trình bày ở Hình 1 . WHC của tôm thể hiện độ săn chắc của cơ thịt tôm. Kết quả cho thấy WHC có xu hướng tăng dần theo thời gian bảo quản, dao động từ 97,3-98,7\% trong suốt 12 ngày bảo quản. Nguyên nhân khả năng giữ nước tăng dần là do mẫu tôm bị mất nước trong quá trình bảo quản, cấu trúc mềm đi. Do đó, ẩm độ của mẫu tôm giảm dần theo thời gian bảo quản (Bảng 4) và giá trị WHC tăng lên. Ở ngày thu mẫu đầu tiên, mẫu có xử lý dịch chiết diệp hạ châu nồng độ $156 \mu \mathrm{g} / \mathrm{mL}$ có giá trị WHC cao hơn so với mẫu đối chứng, tuy nhiên sau 12 ngày bảo quản, WHC của mẫu có xử lý dịch chiết ở nồng độ $7,71 \mu \mathrm{g} / \mathrm{mL}$ lại thấp hơn mẫu đối chứng và khác biệt có ý nghĩa thống kê $(p<0,05)$. Sự thay đổi khả năng giữ nước có thể do hoạt động của enzyme nội tại, liên kết của cơ thịt giảm và sự phân giải protein (Olsson et al., 2003). Theo nghiên cứu của Bak et al. (1999), quá trình oxy hóa lipid cũng liên quan đến sự biến tính protein, làm mất khả năng giữ nước và làm thay đổi cấu trúc trong cơ thịt. Kết quả cho thấy xử lý dịch chiết diệp hạ châu có ảnh hưởng đến khả năng giữ nước của sản phẩm trong thời gian bảo quản lạnh.

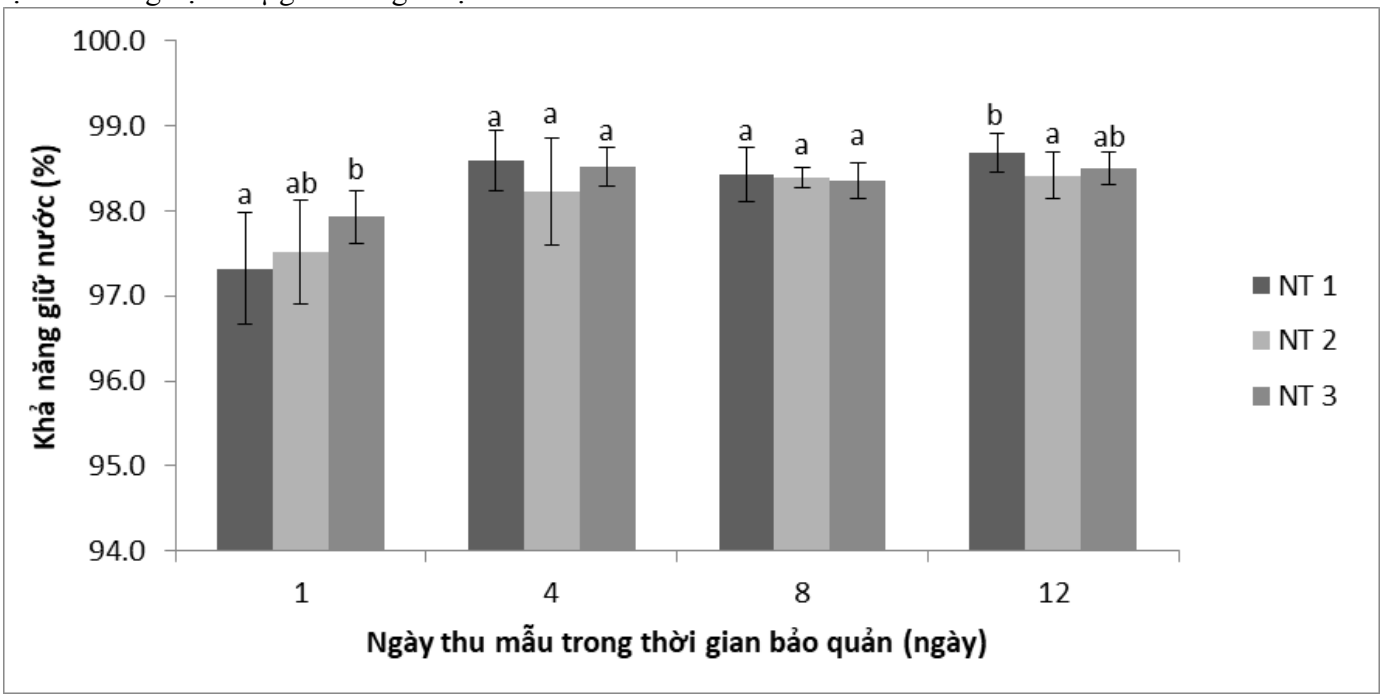

\section{Hình 1. Sự thay đổi khả năng giữ nước (\%) của tôm theo thời gian bảo quản lạnh do tác động của dịch chiết diệp hạ châu}

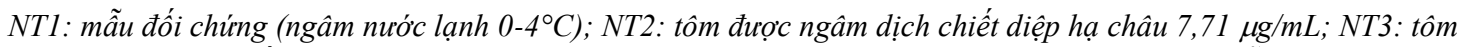
được ngâm dịch chiết diệp hạ châu $156 \mu \mathrm{g} / \mathrm{mL}$. Các chũ cái khác nhau trong cùng một ngày thu mẫu khác biệt có ý nghĩa thống kê $(p<0,05)$

\subsection{4. Âm độ}

Ẩm độ của tôm sú trong thời gian bảo quản được trình bày ở Bảng 2 .

Trong quá trình bảo quản, cơ thịt tôm bị mất nước là nguyên nhân làm cho giá trị ẩm độ có xu hướng giảm. Kết quả phân tích ẩm độ của mẫu tôm ở 3 nghiệm thức khác biệt có ý nghĩa thống kê trong các ngày thu mẫu $1,4,12(p<0,05)$. Nhìn chung, mẫu có xử lý dịch chiết có ẩm độ thấp hơn mẫu đối chứng và dao động trong khoảng 78,1-81,0\% trong suốt quá trình bảo quản. Nguyên nhân ẩm độ trong cơ thit tôm giảm dần theo thời gian bảo quản là do lượng nước tự do đã thoát ra, đồng thời quá trình tự phân giải và biến tính của protein làm cơ thịt tôm lỏng lẻo (Tsuchiya et al.,1992) Bảng 2. Ẩm độ $(\%)$ của tôm theo thời gian bảo quản lạnh do tác động của dịch chiết diệp hạ châu

\begin{tabular}{lcccr}
\hline \multirow{2}{*}{ Nghiệm thức } & \multicolumn{4}{c}{ Ngày thu mẫu trong thời gian bảo quản (ngày) } \\
\cline { 2 - 5 } & $\mathbf{1}$ & $\mathbf{4}$ & $\mathbf{8}$ & $\mathbf{1 2}$ \\
\hline NT1 & $81,0 \pm 0,52^{\mathrm{c}}$ & $80,0 \pm 0,87^{\mathrm{b}}$ & $78,7 \pm 0,59^{\mathrm{a}}$ & $78,9 \pm 0,42^{\mathrm{b}}$ \\
NT2 & $79,4 \pm 0,74^{\mathrm{a}}$ & $78,3 \pm 1,03^{\mathrm{a}}$ & $79,3 \pm 0,36^{\mathrm{a}}$ & $78,1 \pm 0,92^{\mathrm{a}}$ \\
NT3 & $80,1 \pm 0,37^{\mathrm{b}}$ & $78,9 \pm 0,72^{\mathrm{a}}$ & $79,1 \pm 0,50^{\mathrm{a}}$ & $78,9 \pm 0,87^{\mathrm{b}}$ \\
\hline
\end{tabular}

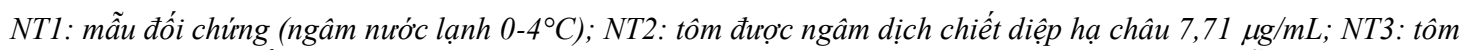
được ngâm dịch chiết diệp hạ châu $156 \mu \mathrm{g} / \mathrm{mL}$. Các chũ cái khác nhau trong cùng một ngày thu mẫu khác biệt có ý nghĩa thống kê $(p<0,05)$ 


\subsection{5. Độ đàn hồi của co thịt tôm}

Kết quả đo độ đàn hồi của tôm sú trong thời gian bảo quản được trình bày ở Bảng 3 .

Trong 4 ngày đầu của quá trình bảo quản kết quả đo độ đàn hồi cơ thịt tôm ở cả 3 nghiệm thức khác biệt không có ý nghĩa thống kê $(p>0,05)$. Tuy nhiên, độ đàn hồi của cơ thịt tôm ở 3 nghiệm thức khác biệt có ý nghĩa thống kê ở hai ngày thu mẫu thứ 8 và 12 $(p<0,05)$. Sau 8 ngày bảo quản, độ đàn hồi của cơ thịt tôm ở NT2 thấp hơn so với hai nghiệm thức còn lại. Tuy nhiên, sau 12 ngày bảo quản, tôm có xử lý dịch chiết lại cho kết quả độ đàn hồi cao hơn mẫu đối chứng. Bảng 5 cho thấy độ đàn hồi của tôm sau 4 ngày bảo quản của tất cả các nghiệm thức cao hơn so với các ngày thu mẫu còn lại do mẫu đã ổn định về nhiệt độ cũng như cấu trúc. Sau 4 ngày bảo quản, độ đàn hồi cơ thịt tôm ở tất cả các mẫu có xu hướng giảm dần. Sự mềm đi của cơ thịt tôm trong quá trình bảo quản là do sự hoạt động của enzyme protease, bên cạnh đó do sự phân hủy các hợp chất protein dưới tác dụng của vi sinh vật và enzyme đặc biệt là enzyme collagenase, làm cho độ đàn hồi của cơ thịt tôm thay đổi đồng thời làm giảm lượng nước trong cơ thịt tôm (Benjakul et al., 1997; Olsson et al., 2003).

Bảng 3. Độ đàn hồi $\left(\mathrm{g}^{*} \mathrm{~cm}\right)$ của tôm theo thời gian bảo quản lạnh do tác động của dịch chiết diệp hạ châu

\begin{tabular}{lrrrr}
\hline \multirow{2}{*}{ Nghiệm thức } & \multicolumn{4}{c}{ Ngày thu mẫu trong thời gian bảo quản (ngày) } \\
\cline { 2 - 5 } & $\mathbf{1}$ & $\mathbf{4}$ & $\mathbf{8}$ & $\mathbf{1 2}$ \\
\hline NT1 & $310 \pm 27,5^{\mathrm{a}}$ & $416 \pm 8,34^{\mathrm{a}}$ & $331 \pm 16,0^{\mathrm{b}}$ & $202 \pm 14,2^{\mathrm{a}}$ \\
NT2 & $320 \pm 20,2^{\mathrm{a}}$ & $418 \pm 18,1^{\mathrm{a}}$ & $303 \pm 6,68^{\mathrm{a}}$ & $218 \pm 21,8^{\mathrm{ab}}$ \\
NT3 & $329 \pm 10,4^{\mathrm{a}}$ & $426 \pm 9,59^{\mathrm{a}}$ & $327 \pm 15,1^{\mathrm{b}}$ & $237 \pm 16,7^{\mathrm{b}}$ \\
\hline
\end{tabular}

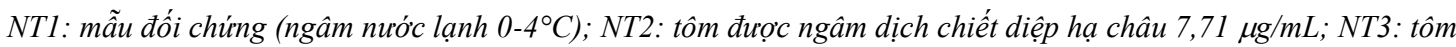
được ngâm dịch chiết diệp hạ châu $156 \mu \mathrm{g} / \mathrm{mL}$. Các chũ cái khác nhau trong cùng một ngày thu mẫu khác biệt có ý nghĩa thống kê $(p<0,05)$

\subsubsection{Tổng hàm luợng nito base bay hoi}

Tổng hàm lượng nitơ base bay hơi (TVB-N) của tôm sú trong suốt thời gian bảo quản lạnh được trình bày ở Hình 2. Giá trị TVB-N được sử dụng như chỉ thị cho sự biến đổi của sản phẩm thủy sản sau khi chết (Olafsdottir et al., 1997). Nhìn chung, hàm lượng TVB-N của các mẫu tôm có xu hướng tăng dần theo thời gian bảo quản. Hàm lượng TVB-N tăng lên trong quá trình bảo quản là do vi sinh vật sinh ra trimethylamine và quá trình tự phân giải của enzyme sản xuất ra dimethylamine, ammoniac được sản xuất bởi phản ứng khử nitơ của các amino acid và catabolites nucleotide và các hợp chất dễ bay hơi khác đạm (Malle \& Poumeyrol, 1989; Ruiz-Capillas $\&$ Moral, 2005).

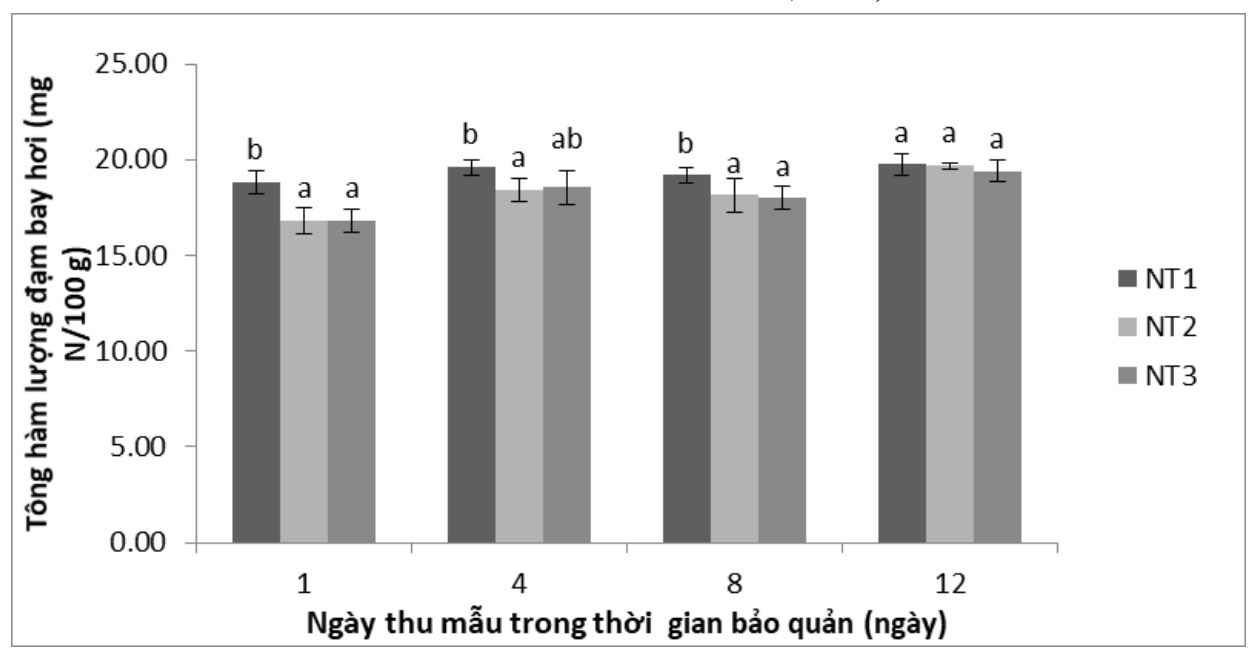

Hình 2. Tổng hàm lượng đạm bay hơi (mg N/100 $\mathrm{g}$ mẫu) của tôm theo thời gian bảo quản lạnh do tác động của dịch chiết diệp hạ châu

NT1: mẫu đối chứng (ngâm nước lạnh 0-4 ${ }^{\circ} \mathrm{C}$ ); NT2: tôm được ngâm dịch chiết diệp hạ châu 7,71 $\mu \mathrm{g} / \mathrm{mL}$; NT3: tôm được ngâm dịch chiết diệp hạ châu $156 \mu \mathrm{g} / \mathrm{mL}$. Các chũ cái khác nhau trong cùng một ngày thu mẫu khác biệt có ý nghĩa thống kê $(p<0,05)$ 
Hình 2 cho thấy giá trị TVB-N ở nghiệm thức đối chứng cao hơn và khác biệt có ý nghĩa thống kê so với mẫu có xử lý dịch chiết ở ngày thu mẫu 1,4 , $8(p<0,05)$. Mẫu tôm xử lý dịch chiết diệp hạ châu có hàm lượng TVB-N thấp hơn mẫu đối chứng cho thấy dịch chiết diệp hạ châu đã thể hiện tác dụng trong việc làm giảm sự tạo thành các hợp chất nitơ bazơ bay hơi sau 8 ngày bảo quản. Giá trị TVB-N dao động từ 16,8 đến $19,8 \mathrm{mgN} / 100 \mathrm{~g}$ trong suốt quá trình bảo quản và kết quả trong nghiên cứu này thấp hơn $50 \mathrm{mg} \mathrm{N} / 100 \mathrm{~g}$ theo tiêu chuẩn của Pike \& Hardy (1997) mà đảm bảo sản phẩm vẫn còn sử dụng được. Kết quả thí nghiệm tương đồng với kết quả nghiên cứu của Nirmal et al. (2011) về sự thay đổi TVB-N của tôm thẻ trong việc sử dụng dịch chiết trà xanh kết hợp với bao gói MPA trong 10 ngày bảo quản ở $4^{\circ} \mathrm{C}$.

\subsubsection{Chỉ số peroxyde (PV)}

Sự biến đổi chỉ số peroxyde (PV) và TBARs của tôm sú trong quá trình bảo quản lạnh được thể hiện ở Bảng 4. Trong nghiên cứu này, giá trị $\mathrm{PV}$ được dùng để xác định sự hình thành các sản phẩm oxy hóa sơ cấp trong quá trình bảo quản lạnh tôm sú. Kết quả phân tích giá trị PV cho thấy khác biệt không có ý nghĩa thống kê ở các ngày thu mẫu $1,4,8$ $(p>0,05)$. Tuy nhiên, sau 12 ngày bảo quản, các mẫu xử lý với dịch chiết có giá trị $\mathrm{PV}$ thấp hơn và khác biệt có ý nghĩa thống kê so với mẫu đối chứng $(p<0,05)$. Do đó trong nghiên cứu này mẫu xử lý dịch chiết diệp hạ châu $7,71 \mu \mathrm{g} / \mathrm{mL}$ và $156 \mu \mathrm{g} / \mathrm{mL}$ chỉ thể hiện việc ức chế sự hình thành sản phẩm oxy hóa lipid sơ cấp sau 12 ngày bảo quản lạnh. Giá trị $\mathrm{PV}$ trong nghiên này dao động trong khoảng từ 2,533,93 (meq/ $/ \mathrm{kg})$ thấp hơn so với mức độ chấp nhận về giá trị PV cho sự oxy hóa của chất béo là 10-20 meq/kg mẫu (Huss, 1995) và thấp hơn so với nghiên cứu của Okpala et al. (2014) trong bảo quản lạnh tôm thẻ chân trắng. $\mathrm{PV}$ từ ngày 1 đến ngày 8 có xu hướng tăng sau đó giảm vào ngày 12 . PV giảm là do các sản phẩm sơ cấp bị oxy hóa thành các sản phẩm thứ cấp (Lindsay,1991; Boselli et al., 2005). Theo Alghazeer et al. (2008), $\mathrm{PV}$ là sản phẩm sơ cấp của quá trình oxy hóa lipid, chúng không bền nên dễ bị oxy hóa tiếp để tạo thành các sản phẩm thứ cấp như andehyde. Do đó, chỉ số $\mathrm{PV}$ tăng hay giảm là hoàn toàn phụ thuộc vào sự tương quan giữa tốc độ hình thành hợp chất peroxyde và tốc độ phân hủy hợp chất peroxyde thành các sản phẩm thứ cấp.

Bảng 4. Chỉ số peroxyde value (PV, meq/kg) và Thiobarbituric acid reactive substances (TBARs; mg MDA/kg) của tôm theo thời gian bảo quản lạnh do tác động của dịch chiết diệp hạ châu

\begin{tabular}{|c|c|c|c|c|c|c|}
\hline \multirow[t]{2}{*}{ Ngày } & \multicolumn{3}{|c|}{ Peroxyde value; PV, meq/kg } & \multicolumn{3}{|c|}{$\begin{array}{c}\text { Thiobarbituric acid reactive substances; } \\
\text { TBARs, mg MDA/kg }\end{array}$} \\
\hline & NT1 & NT2 & NT3 & NT1 & NT2 & NT3 \\
\hline 1 & $3,13 \pm 0,55^{a}$ & $2,80 \pm 0,51^{\mathrm{a}}$ & $2,53 \pm 0,71^{\mathrm{a}}$ & $0,66 \pm 0,09^{\mathrm{a}}$ & $0,58 \pm 0,10^{\mathrm{a}}$ & $0,63 \pm 0,06^{\mathrm{a}}$ \\
\hline 4 & $3,33 \pm$ & $3,07 \pm 0,5$ & $2,89 \pm 0,56^{\mathrm{a}}$ & $0,66 \pm 0,03^{b}$ & $0,61 \pm 0,09^{\mathrm{ab}}$ & $0,58 \pm 0,07^{\mathrm{a}}$ \\
\hline 8 & $3,93 \pm 0,49^{\mathrm{a}}$ & $3,23 \pm 0,62^{\mathrm{a}}$ & $3,07 \pm 0,61^{\mathrm{a}}$ & $0,78 \pm 0,09^{b}$ & $0,63 \pm 0,09^{\mathrm{a}}$ & $0,68 \pm 0,06^{\mathrm{a}}$ \\
\hline 12 & $3,03 \pm 0,17^{b}$ & $2,73 \pm 0,13^{\mathrm{a}}$ & $2,73 \pm 0,08^{\mathrm{a}}$ & $0,85 \pm 0,04^{b}$ & $0,79 \pm 0,07^{\mathrm{ab}}$ & $0,75 \pm 0,07^{\mathrm{a}}$ \\
\hline
\end{tabular}

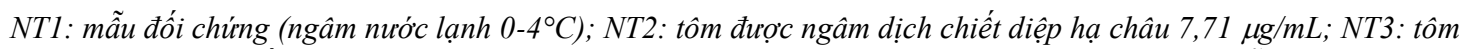
được ngâm dịch chiết diệp hạ châu $156 \mu \mathrm{g} / \mathrm{mL}$. Các chũ cái khác nhau trong cùng một ngày thu mẫu của tùng chỉ tiêu phân tích khác biệt có ý nghĩa thống kê $(p<0,05)$

\subsubsection{Chì số TBARs}

Chỉ số TBARs thể hiện các sản phẩm oxy hóa thứ cấp trong quá trình oxy hóa chất béo như aldehydes, ketones, alcohols, carboxylic acids, alkanes (Benjakul et al., 2005). Bảng 4 cho thấy giá trị TBARs của các mẫu có ngâm dịch chiết diệp hạ châu có giá trị TBARs thấp hơn và khác biệt có ý nghĩa thống kê so với mẫu đối chứng ở các ngày thu mẫu $4,8,12(p<0,05)$. Giá trị TBARs của cả 3 nghiệm thức tăng theo thời gian bảo quản và dao động từ $0,58-0,85 \mathrm{mg} \mathrm{MDA} / \mathrm{kg}$, thấp hơn so với mức độ chấp nhận về giá trị TBARs cho sự oxy hóa của chất béo là 5-8 mg MDA/kg (Sallam, 2007). Trong nghiên cứu này, giá trị TBARs của mẫu sử dụng dịch chiết diệp hạ châu luôn thấp hơn mẫu đối chứng cho thấy khả năng chống oxi hóa của dịch chiết diệp hạ châu sử dụng trong bảo quản lạnh tôm sú. Kêt quả nghiên cứu này thấp hơn so với nghiên cứu Nguyễn Xuân Duy và Nguyễn Anh Tuấn (2013) trong việc sử dụng dịch chiết lá ổi để bảo quản lạnh tôm thẻ chân trắng và tương đồng với kết quả của Nirmal and Benjakul (2011) trong thời gian 10 ngày bảo quản lạnh tôm thẻ có xử lý với dịch chiết trà xanh kết hợp bao gói MAP.

\subsection{Tổng số vi khuẩn hiếu khí (TVC) của tôm sú theo thời gian bảo quản}

Tổng số vi khuẩn hiếu khí (TVC) của tôm sú trong suốt 12 ngày bảo quản lạnh được trình bày trong Hình 3. 


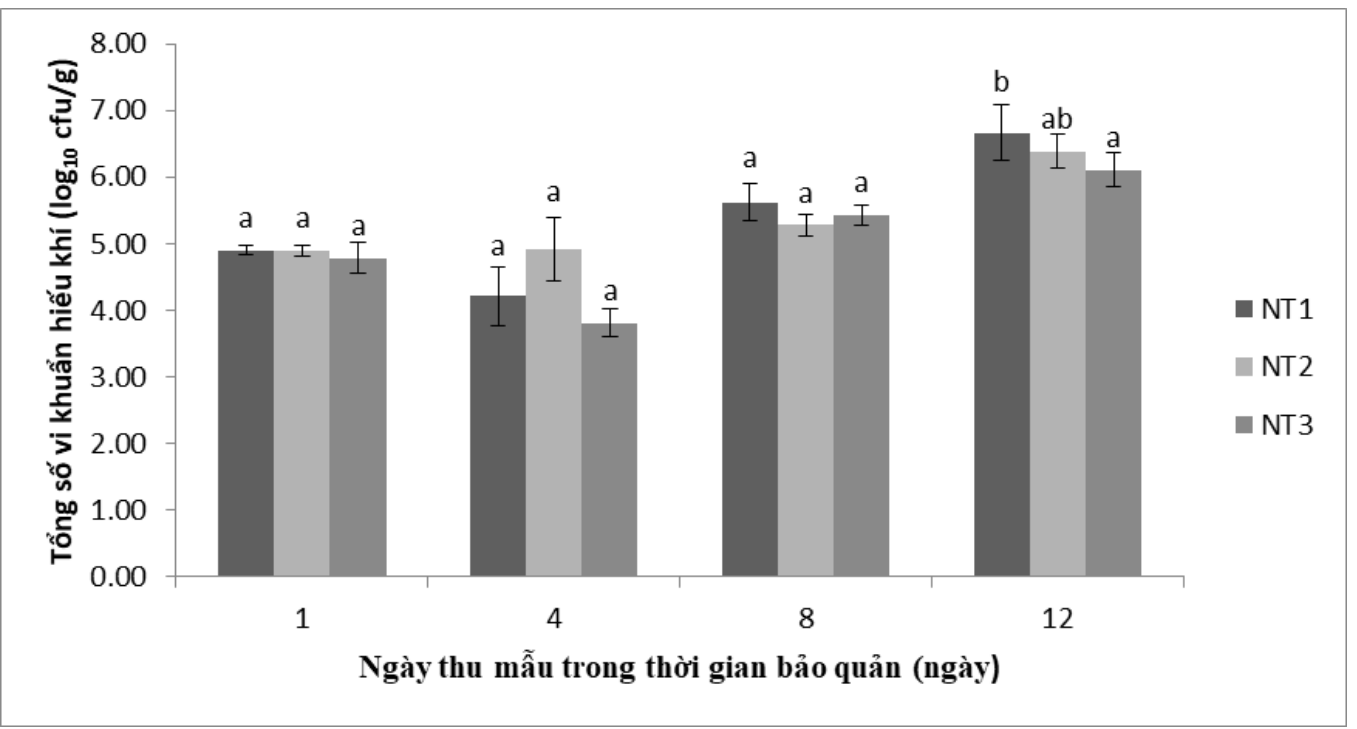

\section{Hình 3. Tổng số vi khuẩn hiếu khí ( $\left.\log _{10} \mathrm{cfu} / \mathrm{g}\right)$ của tôm theo thời gian bảo quản lạnh do tác động của dịch chiết diệp hạ châu}

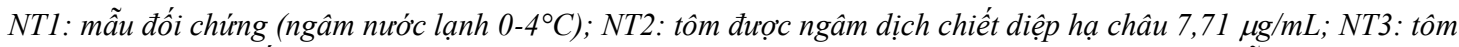
được ngâm dịch chiết diệp hạ châu $156 \mu \mathrm{g} / \mathrm{mL}$. Các chũ cái khác nhau trong cùng một ngày thu mẫu khác biệt có ý nghĩa thống kê $(p<0,05)$

Hình 3 cho thấy giá trị TVC ở 3 nghiệm thức khác biệt không có ý nghĩa thống kê sau 8 ngày bảo quản $(p>0,05)$. Sau 12 ngày bảo quản, kết quả phân tích cho thấy TVC của mẫu đối chứng $\left(\log _{10} \mathrm{cfu} / \mathrm{g}=\right.$ $6,66)$ cao hơn và khác biệt có ý nghĩa thống kê so với mẫu ngâm dịch chiết diệp hạ châu nồng độ 156 $\mu \mathrm{g} / \mathrm{mL}\left(\log _{10} \mathrm{cfu} / \mathrm{g}=6,10\right)(p<0,05)$. Sau 12 ngày bảo quản, giá trị TVC của cả 3 nghiệm thức đều vượt quá giới hạn cho phép $10^{6} \mathrm{cfu} / \mathrm{g}$ theo quyết định của Bộ Y tế (2012). Kết quả cho thấy mẫu xử lý dịch chiết diệp hạ châu nồng độ $156 \mu \mathrm{g} / \mathrm{mL}$ có hoạt tính ức chế hoạt động và hạn chế sự phát triển vi sinh vật ở ngày 12 của quá trình bảo quản lạnh tôm sú. Kết quả giá trị TVC trong nghiên cứu này tương đồng với kết quả nghiên cứu của Yuan et al. (2016a) về sử dụng dịch chiết vỏ quả lựu kết hợp chitosan trong 10 ngày bảo quản lạnh tôm thẻ chân trắng, có giá trị TVC tăng dần theo thời gian bảo quản và khác biệt rõ rệt ở giai đoạn cuối của quá trình bảo quản.

\subsection{Giá trị cảm quan của tôm sú trong thời gian bảo quản}

Sự thay đổi về giá trị cảm quan của mẫu tôm tươi và tôm sú sau khi hấp trong quá trình bảo quản lạnh được trình bày lần lượt ở Hình 4 và Hình 5 . Hình 4 thể hiện giá trị cảm quan đánh giá trên mẫu tươi theo tiêu chuẩn chỉ số chất lượng của các nghiệm thức tăng dần theo thời gian bảo quản và dao động từ 0 -
9,43; cho thấy chất lượng của tôm giảm dần theo thời gian bảo quản. Ở ngày bảo quản thứ 8 và 12 , giá trị cảm quan của tôm tươi có xử lý diệp hạ châu cao hơn và khác biệt có ý nghĩa thống kê so với mẫu đối chứng $(p<0,05)$. Kết quả cho thấy mẫu xử lý diệp hạ châu có tác dụng đến chất lượng cảm quan tôm tươi. Mẫu đối chứng có màu sắc của thân tôm từ sáng bóng sang bạc nhẹ, đầu tôm xanh đậm, có dấu hiệu biến đen và có hiện tượng long đầu, thịt tôm kém trong hơn so với mẫu được xử lý dịch chiết. Đến ngày 12 , thân tôm bị giãn đốt và hiện tượng long đầu rõ rệt, thịt tôm kém đàn hồi và săn chắc hơn, xuất hiện mùi khai nhẹ. Tuy nhiên, kết quả phân tích tổng vi khuẩn hiếu khí cho thấy sản phẩm không thể sử dụng được vì tổng số vi khuẩn hiếu khí cao hơn $10^{6} \mathrm{cfu} / \mathrm{g}$ ở ngày 12 . Hiện tượng biến đen ở tôm là do sự biến đổi của tyrosine thành melanin nhờ tyrosinaza trong môi trường bảo quản có oxy (Lê Thị Xuyến, 1996). Chất lượng cảm quan tôm giảm trong quá trình bảo quản là do tác động của enzyme và vi sinh vật (Hsieh \& Kinsella, 1989) làm thay đổi các tính chất hóa lí của protein cơ thịt, cùng với đó là sự phát triển của vi sinh vật gây hư hỏng phân giải các thành phần có trong cơ thịt tôm nên làm cho mẫu mềm và có mùi khó chịu. Bền cạnh đó, sự oxy hóa lipid cũng làm cho thực phẩm có mùi ôi do tạo ra các sản phẩm cấp thấp. 


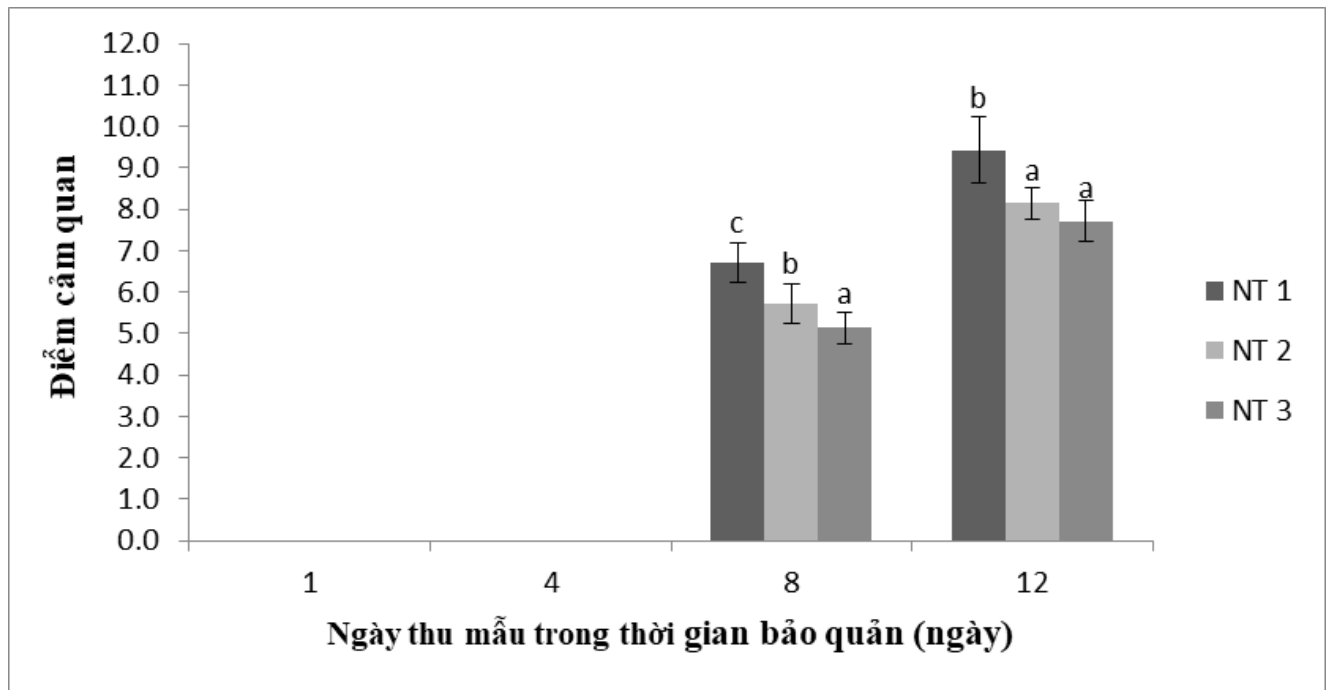

Hình 4. Sự thay đổi giá trị cảm quan của tôm theo thời gian bảo quản lạnh do tác động của dịch chiết diệp hạ châu (đánh giá mẫu tươi theo chỉ số chất lượng, QIM)

NT1: mẫu đối chứng (ngâm nước lạnh 0-4 ${ }^{\circ} \mathrm{C}$ ); NT2: tôm được ngâm dịch chiết diệp hạ châu 7,71 $\mu \mathrm{g} / \mathrm{mL}$; NT3: tôm được ngâm dịch chiết diệp hạ châu $156 \mu \mathrm{g} / \mathrm{mL}$. Các chũ cái khác nhau trong cùng một ngày thu mẫu khác biệt có ý nghĩa thống kê $(p<0,05)$

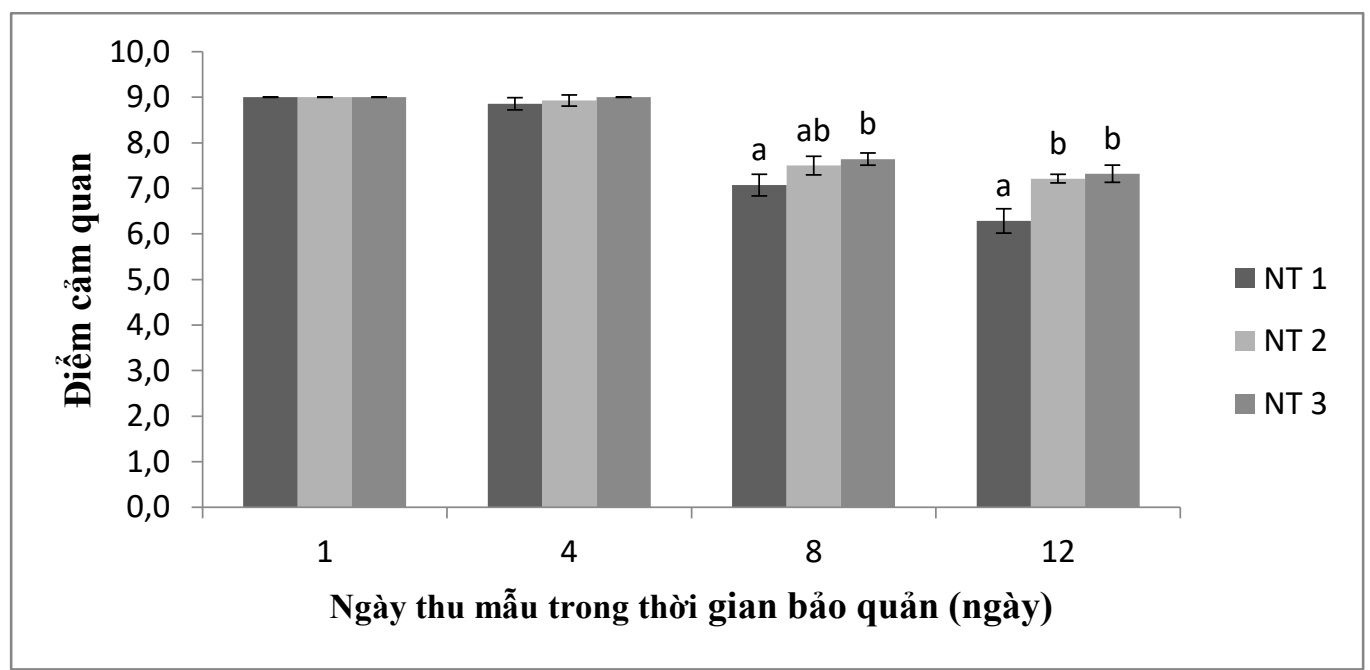

Hình 5. Sự thay đổi giá trị cảm quan của tôm theo thời gian bảo quản lạnh do tác động của dịch chiết diệp hạ châu (mẫu sau khi hấp)

NT1: mẫu đối chứng (ngâm nước lạnh 0-4 ${ }^{\circ} \mathrm{C}$ ); NT2: tôm được ngâm dịch chiết diệp hạ châu 7,71 $\mu \mathrm{g} / \mathrm{mL}$; NT3: tôm được ngâm dịch chiết diệp hạ châu $156 \mu \mathrm{g} / \mathrm{mL}$. Các chũ cái khác nhau trong cùng một ngày thu mẫu khác biệt có ý nghĩa thống kê $(p<0,05)$

Sự thay đổi giá trị cảm quan của tôm sú theo thời gian bảo quản lạnh do tác động của dịch chiết diệp hạ châu (mẫu sau khi hấp) được minh họa trong Hình 5 . Trong 4 ngày đầu của quá trình bảo quản, giá trị cảm quan của sản phẩm tôm sú hấp khác biệt không có ý nghĩa thống kê ở 3 nghiệm thức $(p>0,05)$. Sau 8 và 12 ngày bảo quản, mẫu có xử lý dịch chiết có giá trị cảm quan cao hơn và khác biệt có ý nghĩa thống kê so với mẫu đối chứng $(p<0,05)$. Ngoài ra, giá trị cảm quan mẫu xử lý diệp hạ châu nồng độ $7,71 \mu \mathrm{g} / \mathrm{mL}$ và $156 \mu \mathrm{g} / \mathrm{mL}$ khác biệt không có ý nghĩa thống kê ở các ngày thu mẫu $(p>0,05)$. Nhìn chung màu sắc của tôm hấp ít bị biến đổi vì khi gia nhiệt màu sắc của tôm chuyển sang đỏ gạch (hay đỏ cam) làm tăng giá trị cảm quan của tôm so với trước khi hấp. Sau 8 ngày bảo quản, tôm sau hấp đều 
có mùi thơm đặc trưng, tuy nhiên sau 12 ngày bảo quản, tôm xuất hiện mùi khai khó ngửi, có thể là do trong quá trình bảo quản phân giải protein tạo ra $\mathrm{NH}_{3}$ làm cho tôm biến màu và mùi vị (Ruiz-Capillas \& Moral, 2005; Boselli et al., 2005). Qua đó cho thấy về chất lượng cảm quan ở mẫu tươi và sau khi hấp của tôm sú ở nghiệm thức có ngâm dịch chiết diệp hạ châu có chất lượng tốt hơn so với mẫu đối chứng.

\section{KẾT LUẬN}

Kết quả nghiên cứu bảo quản lạnh tôm sú bằng dịch chiết diệp hạ châu đã cải thiện giá trị cảm quan của tôm, có mùi thơm hơn, độ đàn hồi cũng được duy trì tốt hơn so với mẫu đối chứng. Đồng thời, mẫu xử lý diệp hạ châu có khả năng ức chế sự hình thành sản phẩm oxy hóa sơ cấp và thứ cấp. Dịch chiết diệp hạ châu cũng có hoạt tính ức chế hoạt động và hạn chế sự phát triển vi sinh vật trong thời gian bảo quản lạnh tôm sú. Dựa trên giá trị tổng vi khuẩn hiếu khí và giá trị cảm quan, tôm sú có hay không có xử lý diệp hạ châu có thể sử dụng đến 8 ngày trong điều kiện bảo quản lạnh.

\section{LÒ̀I CẢM TẠ}

Đề tài này được tài trợ bởi Dự án Nâng cấp Trường Đại học Cần Thơ VN14-P6 bằng nguồn vốn vay ODA từ Chính phủ Nhật Bản. Nhóm tác giả cám ơn sinh viên Trà Thị Lẹ đã hỗ trợ thực hiện đề tài này.

\section{TÀI LIỆU THAM KHẢO}

Alghazeer, R., Saeed, S., \& Howell, N. K. (2008). Aldehyde formation in frozen mackerel (Scomber scombrus) in the presence and absence of instant green tea. Food Chemistry, 108(3), 801-810.

AOAC. (2016). Official methods of Analysis of AOAC International, $20^{\text {th }}$ Ed. George W. Latimer, Jr (Eds.). Volume I.

Bak, L. S., Andersen, A. B., Andersen, E. M., \& Bertelsen, G. (1999). Effect of modified atmosphere packaging on oxidative changes in frozen stored cold water shrimp (Pandalus borealis). Food Chemistry, 64(2), 169-175

Benjakul, S., Seymour, T. S., Morrissey, M. T., \& An, H. (1997). Physiochemical changes in Pacific whitting muscle proteins during iced storage. Journal of Food Science, 62, 729-733.

Benjakul, S., Visessanguan, W., Phongkanpai, V., \& Tanaka, M. (2005). Antioxidative activity of caramelization products and their preventive effect on lipid oxidation in fish mince. Food Chemistry, 90(1-2), 231-239.
Bộ Y tế. (2012). Quy chuẩn kỹ thuật quốc gia đối với ô nhiễm vi sinh vật trong thực phẩm QCVN 83:2012/BYT.

http://www.fsi.org.vn/pic/files/qcvn-8-3_2011byt-ve-o-nhiem-vi-sinh-vat-trongtp_bia_merged.pdf.

Boselli, E., Caboni, M. F., Redriguez-Estrada, M. T., Toschi, T. G., Daniel, M., \& Lercker, G. (2005). Photoxidation of cholesterol and lipids of turkey meat during storage under commercial retail conditions. Food Chemistry, 91(4), 705-713.

Cos, P., Vlietinck A. J., Berghe, D. V., \& Maes, L. (2006). Anti-infective potential of natural products: How to develop a stronger in vitro 'proof of concept'. Journal Ethnopharmacol, 106(3), 290-302.

Duun, A. S. \& Rustad, T. (2007). Quality changes during superchilled storage of cod (Gadus morhua) fillets. Food Chemistry, 105(3), 1067-1075.

Dương Thị Phượng Liên, Bùi Thị Quỳnh Hoa và Nguyễn Bảo Lộc. (2011). Đánh giá nhanh độ tươi tôm sú nguyên liệu (Penaeus monodon) bảo quản trong nước đá $\left(0-4^{\circ} \mathrm{C}\right)$ theo phương pháp chỉ số chất lượng QIM. Tạp chi khoa học Trường Đại học Cần Tho, 18b, 53-62.

Gunalan, B. S. N. T., Nina, T. S., Soundarapandian, P., \& Anand, T. (2013). Nutritive value of cultu red white leg shrimp Litopenaeus vannamei. International Journal of Fisheries and Aquaculture, 5(7), 166 - 171

Hsieh, R., \& Kinsella, J. E. (1989). Oxydation of polyunsaturated fatty acids: mechanisms, products and inhibition with emphasis on fish. Advances in Food and Nutrition Research, 33, 233-341.

Hultmann, L., Phu, T. M., Tobiassen, T., Aas-Hansen, Ø., \& Rustad, T. (2012). Effects of pre-slaughter stress on proteolytic enzyme activities and muscle quality of farmed Atlantic cod (Gadus morhua). Food chemistry, 134(3), 1399-1408.

Huss, H. H. (1995). Quality and quality changes in fresh fish, FAO Fisheries Technical Paper. No. 348. Rome.

Le Anh Dao, N., Phu, T.M., Douny, C., QuetinLeclercq, J., Hue, B.T.B., Bach, L.T., Quynh Nhu, T., Thi Bich Hang, B., Thi Thanh Huong, D., Thanh Phuong, N., \& Kestemont, P. (2020). Screening and comparative study of in vitro antioxidant and antimicrobial activities of ethanolic extracts of selected Vietnamese plants. International Journal of Food Properties, 23(1), 481-496.

Lê Thị Xuyến. (1996). Vi sinh vật chế biến thực phẩm thủy sản (phần II). Nhà Xuất Bản Đại Học Nha Trang.

Lindsay, R. C. (1991). Flavour of fish. Paper presented at 8th World Congress of Food 
Science and Technology, 29th September-4th October, Toronto, Canada.

Maity, S., Chatterjee, S., Varryar, S., Sharma, A., Adhikari, S., \& Mazumder, S. (2013). Evaluation of antioxidant activity and characterization of phenolic constituents of Phyllanthus amarus root. Journal of agricultural and food chemistry, 61(14), 3443-3450.

Malle, P. \& Poumeyrol, M. (1989). A new chemical criterion for the quality control of fish: trimethylamine/total volatile basic nitrogen (\%). Journal of food protection, 52(6), 419-423.

Meilgaard, M., Civille, G. V., \& Carr, B. T. (1999). Sensory evaluation techniques (3rd ed), CRC Press, Boca Raton, FL.

Nguyễn Xuân Duy \& Nguyễn Anh Tuấn. (2013). Sàng lọc thực vật có hoạt tính chống oxi hóa và áp dụng trong chế biến thủy sản. Tạp chi Khoa hoc Trường Đại học Cần Tho: Phần B: Nông nghiệp, Thủy sản và Công nghệ Sinh họ, 28, 59-68

Nirmal, N. P., \& Benjakul, S. (2011). Retardation of quality changes of Pacific white shrimp by green tea extract treatment and modified atmosphere packaging during refrigerated storage.

International Journal of Food Microbiology, 149(3), 247-253.

Ofstad, R., Kidman, S., Myklebust, R., \& Hermansson, A. M. (1993). Liquid holding capacity and structural changes during heating of fish muscle: cod (Gadus morhua L.) and salmon (Salmo salar). Food structure, 12(2), 4.

Okpala, C. O. R., Choo, W. S., \& Dykes, G. A. (2014). Quality and shelf life assessment of Pacific white shrimp (Litopenaeus vannamei) freshly harvested and stored on ice. LWT-Food Science and Technology, 55(1), 110-116.

Olafsdottir, G., Martinsdóttir, E., Oehlenschläger, J., Dalgaard, P., Jensen, B., Undeland, I., ... \& Nilsen, H. (1997). Methods to evaluate fish freshness in research and industry. Trends in food science \& technology, 8(8), 258-265.

Olsson, G. B., Ofstad, R., Lødemel, J. B., \& Olsen, R. L. (2003). Changes in water-holding capacity of halibut muscle during cold storage. LWT-Food Science and technology, 36(8), 771-778.

Pike, I. H., \& Hardy, R. W. (1997). Standards for assessing quality of feed ingredients. In: L. R. D’Abramo, D. M. Conklin, D. M. Akiyama, (Eds.), Crustacean Nutrition. Advances in World Aquaculture, Vol. 6. World Aquaculture Society, Baton Rouge, LA. 473-492.
Raharjo, S., Sofos, J. N., \& Schmidt, G. R. (1992). Improved speed, specificity, and limit of determination of an aqueous acid extraction thiobarbituric acid-C18 method for measuring lipid peroxidation in beef. Journal of Agricultural and Food Chemistry, 40(11), 2182-2185.

Ruiz-Capillas, C., \& Moral, A. (2005). Sensory and biochemical aspects of quality of whole bigeye tuna (Thunnus obesus) during bulk storage in controlled atmospheres. Food chemistry, 89(3), 347-354.

Sallam, K. I. (2007). Antimicrobial and antioxidant effects of sodium acetate, sodium lactate, and sodium citrate in refrigerated sliced salmon. Food Control, 18(5), 566-575.

Sen, A., \& Batra, A. (2012). Determination of antimicrobial potentialities of different solvent extracts of the medicinal plant: Phyllanthus amarus Schum. and Thonn. International Journal of Green Pharmacy (IJGP), 6(1).

Solanki, R. (2010). Some medicinal plants with antibacterial activity. Int. J. Comp. Pharm, 1(4), 1-4.

Tsuchiya, H., Kita, S. \& Seki, N. (1992) Postmortem changes in $\alpha$-actinin and connectin in carp and rainbow trout muscles. Nippon Suisan Gakkaishi, 58(4), 793-798.

VASEP. 2020. Tổng quan ngành thủy sản Việt Nam. Ngày truy cập 06/07/2020. Truy cập tại http://vasep.com.vn/1192/OneContent/tongquan-nganh.htm

Velho, N. P. S. (2001). Preparation for obtaining accreditation of analytical methods regarding quality issues as stated in ISO standard ISO/IEC 17025:1999. Final project report.

Yuan, G., Lv, H., Tang, W., Zhang, X., \& Sun, H. (2016a). Effect of chitosan coating combined with pomegranate peel extract on the quality of Pacific white shrimp during iced storage. Food Control, 59, 818-823.

Yuan, G., Zhang, X., Tang, W., \& Sun, H. (2016b). Effect of chitosan coating combined with green tea extract on the melanosis and quality of Pacific white shrimp during storage in ice. $C y T A$ Journal of Food, 14(1), 35-40.

Zeng, Q. Z., Thorarinsdottir, K. A., \& Olafsdottir, G. (2005). Quality changes of shrimp (Pandalus borealis) stored under different cooling conditions. Journal of food science, 70(7), s459-s466. 